\title{
Posthumanistyczne otwarcie języka Czym jest post-koiné?
}

\author{
Anita Jarzyna: Post-koiné. \\ Studia o nieantropocentrycznych językach (poetyckich). \\ Łódź, Wydawnictwo Uniwersytetu Łódzkiego, 2019, ss. 577.
}

The Post-Humanist Opening of Language: What is Post-Koiné?

Aвstract: This article is a review of Anita Jarzyna's book Post-koiné. Studia o nieantropocentrycznych językach (poetyckich) [Post-koiné. Studies in Non-anthropocentric (Poetic) Languages]. The reviewer discusses the literary material upon which the book's analysis focuses; the interdisciplinary theoretical basis used by the scholar; the theme of memory, particular the possibilities of writing a "shared" universal history without excluding animals; and, last but not least, the theme of the emotional nature of animals, the possibility of representing it in literature, and the question of the place which animals inhabit in language.

W ostatnim czasie niemalże co roku mogliśmy sięgać w polskim kulturoznawstwie po nową pozycję z dziedziny animal studies czy posthumanistyki - często po studia literaturoznawcze. Co ważne, były wśród nich zarówno tomy zbiorowe, na przykład Zwierzęta $i$ ich ludzie. Zmierzch antropocentrycznego paradygmatu (2015) czy Emancypacja zwierząt? (2015), jak i monografie znacząco napędzające dynamikę tych badań w Polsce, choćby Realizm ekologiczny. Od ekokrytyki do zookrytyki w literaturze polskiej Anny Barcz (2016), „Dlaczego gessi krzyczały?". Zwierzęta i Zagłada w literaturze polskiej XX i XXI wieku Piotra Krupińskiego (2016), (Prze)zwierzęcenia. Poetyckie drogi do postantropocentryzmu Anny Filipowicz (2017), czy również antologia tekstów romantycznych Zwierzęta na zakręcie Beaty Mytych-Forajter (2017). W 2019 roku dołączyła do 
nich praca Post-koiné. Studia o nieantropocentrycznych językach (poetyckich) Anity Jarzyny, naukowczyni z Uniwersytetu Łódzkiego. Autorka zbiera w obszernym, bo ponad pięćsetstronicowym, tomie artykuły, które opublikowała wprawdzie już w poprzednich latach, ale poddaje je daleko idącym zmianom oraz nadaje im wspólny mianownik - tytułowej "post-koiné”, którą można nazwać też nową koiné, będącą efektem „międzygatunkowego otwarcia języka” (s. 12). Taka geneza książki ma odzwierciedlenie w strukturze kolejnych rozdziałów choć na wstępie publikacji otrzymujemy szerokie wprowadzenie, nie tylko prezentujące i komentujące stan badań, ale także otwierające kolejne pola dyskursu postantropocentrycznego, każdy z rozdziałów zawiera własną część dywagacji teoretycznych, poprzedzających konkretne analizy literackie.

Pojęcie „post-koiné” jest tu świadomie wprowadzane do instrumentarium badań polskiej posthumanistyki - będzie zapewne funkcjonować obok zookrytyki (Anna Barcz), zoofilologii (Aleksander Nawarecki) czy biopoetyki (Przemysław Czapliński) jako inne imię języka nieantroponormatywnego. „Post-koiné” jest zarówno postulatem, jak i opisem zjawiska, które już istnieje. Taki nowy język powstaje, gdy jego użytkownik „obdarza troską wykluczonych, obcych, tę resztę, która zawsze zostaje, gdy próbujemy ująć rzeczywistość w jasne kategorie, uporządkować ją dla własnej wygody, gdy nadmiernie przywiązujemy się do centrum” (s. 42). Choć badaczka definiuje „post-koiné” jako „nowy język rozszerzonej inkluzywności, wielogatunkowej wspólnoty” (s. 90), jest to jednak wciąż język (tylko) ludzki (autorka nie zajmuje się tu kontekstem sztucznej inteligencji), wyróżniający się wszak otwarciem na pozaludzkie istnienia. Jego inną istotną cechą jest daleko idąca samorefleksja, „post-koiné” krytycznie przygląda się zastanemu słownikowi wspólnoty, również słownikowi dyscyplin humanistycznych.

Jarzyna łączy w tomie swoje najważniejsze zainteresowania naukowe: badania nad poezją, studia nad Zagładą i nad zwierzętami. Post-koiné... realizuje kolejny etap rozwoju studiów nad posthumanistyką na przykładzie języka literatury i przedstawień literackich. Autorka skupia się (głównie) na polskich tekstach literackich (nie tylko na poezji) XX i XXI wieku w różny sposób opowiadających się po stronie zwierząt nieludzkich i próbujących przyjąć ich perspektywę, tekstach podważających binarną opozycję człowiek - zwierzę.

Zadeklarowanym celem książki jest zbudowanie - czy może zrekonstruowanie - „wielowątkowej narracji o krytycznym języku relacji ze zwierzętami wyłaniającej się z poezji polskiej drugiej połowy XX wieku i początku XXI wieku” (s. 43), Anita Jarzyna uważa bowiem poezję za szczególnie „czułą sondę” kultury. Badaczka nazywa swoją publikację „monografią kontekstową”, w kolejnych rozdziałach faktycznie wychodzi od konkretnych zjawisk/wydarzeń, dopiero przy drugim kroku dochodząc do tekstów literackich (często - poetyckich). Wydaje mi się, że autorka wchodzi też w konkretne gniazda tematyczne. Kierunek rozdziałom monografii nadają cztery hasła porządkujące. Część zatytułowana 
Innymi słowy pełni funkcję szerokiego wprowadzenia nie tylko w problematykę „post-koiné”, ale zasadniczo w sferę studiów posthumanistycznych. W następnej części książki, Stany wyjątkowe. Status quo, badaczka zajmuje się przede wszystkim (literackim, poetyckim) językiem opisu Zagłady, traktując najpierw o zagładzie Ormian (1915-1917) i - zdaniem Jarzyny zapowiadającej ją na poziomie metafory - rzezi psów w Stambule (1910). Bohaterami kolejnego bloku tematycznego - Obyczaje - stają się anonimowe zwierzęta hodowlane prowadzone na rzeź, dzikie zwierzęta będące ofiarami polowań (odpowiednio obecność „współczującej wyobraźni” w poezji Tadeusza Śliwiaka, Jerzego Kronholda, Tadeusza Nowaka, Jerzego Ficowskiego, Anny Kamieńskiej) i w końcu anonimowe, ale też znane $\mathrm{z}$ imienia zwierzęta poddawane eksperymentom naukowym (niekoniecznie medycznym): Łajka oraz Biełka i Striełka. To również miejsce na równoległe wprowadzenie tematu macierzyństwa i porodu - ludzkiego oraz zwierzęcego.

W ostatniej części - Wspólny świat: od-nowa - badaczka zajmuje się między innymi obecnością ptaków w języku poetyckim i miejscem uczuć w świecie postantropocentrycznym, ale wychodzi także na chwilę poza sferę zwierząt (ludzkich czy nieludzkich), opisując jako „przyrodopisarstwo” (s. 455) twórczość Michała Książka. Jarzyna sugeruje zatem, że język naszej współczującej wrażliwości może objąć jeszcze dalsze obszary, wciąż przez nas wykluczane, marginalizowane, niemające de facto żadnych praw: świat drzew, lasów, puszcz, rzek, jezior, słowem - natury, w którą człowiek ingeruje, którą eksploatuje i coraz bardziej niszczy. Wydaje się, że po aktywnej walce o prawa zwierząt potrzebujemy coraz wyraźniej nowego języka, który mógłby się upomnieć również o prawa roślin.

\section{Wchodzenie w (liryczne) teksty}

Najstarsze z tekstów literackich, do których odwołuje się łódzka naukowczyni, powstały w pierwszej połowie XX wieku, najmłodsze przed kilkoma laty - klucz poetycki nie jest tu jedynym, jakim posługuje się badaczka przy doborze materiału do analizy. Wydaje się, że najważniejsza dla niej kwestia to pokazanie "poetycki[ch] gest[ów] sprzeciwu wobec antroponormatywnych języków przemocy w stosunku do zwierząt" (s. 531). Anita Jarzyna pyta, na ile język poetycki mógłby oddać perspektywę podmiotów nieludzkich; jest świadoma tego, że literatura to miejsce, w którym możemy osłabiać ludzką podmiotowość, jednocześnie próbując wykreować/przyjąć zwierzęcy punkt widzenia.

Do kilkorga autorów - poetów i poetek - badaczka powraca wielokrotnie na przestrzeni całej książki. Nie zajmuje się przy tym tylko literaturą, ale wyraźnie odwołuje się do biografii oraz postaw życiowych autorów i autorek. Najczęściej 
pojawiają się tu: Jerzy Ficowski, Jacek Podsiadło i Krystyna Miłobędzka. Obecne są również pojedyncze utwory Józefa Czechowicza, Zuzanny Ginczanki, Tadeusza Różewicza, Tadeusza Śliwiaka, Tadeusza Nowaka, Zbigniewa Herberta, Adama Włodka, Anny Kamieńskiej, Joanny Pollakówny, Adama Zagajewskiego, Justyny Bargielskiej czy Piotra Sommera. Podaję tylko niektóre z długiej listy nazwisk - badaczka czyta i niejako przepisuje poezję, zwracając uwagę na jej (i autorów) stosunek do cierpienia zwierząt. Mowa tu między innymi o antycypacji Zagłady w Śmierci (1929) Józefa Czechowicza i Łowach (1937) Zuzanny Ginczanki, o animalizacji ofiar w przypadku opisów Szoa, o wierszu Naprzód pies (1957) Zbigniewa Herberta, „poety współodczucia” (s. 362), któremu nie były obojętne losy psów (czy ogólnie: zwierząt) wykorzystywanych w „radzieckim programie kosmicznym", o kolejnych lirykach Jerzego Ficowskiego przeczuwającego, że "zwierzęta na własny sposób doświadczają tajemnicy istnienia” (s. 421), i w końcu o „Zwierzęcym, dziecięcym i poetyckim” w poezji Justyny Bargielskiej (s. 337). Jednym z autorów, do których poezji badaczka najczęściej się odwołuje, jest Jacek Podsiadło - dla niego „poznanie siebie jest rozpoznaniem pokrewieństw międzygatunkowych, wyobraźniowym ruchem $\mathrm{w}$ ich stronę" (s. 63). W pewnym sensie stanowi on dla autorki - tak to odczytuję - pars pro toto całej poezji zajmującej się samopoznaniem i - w konsekwencji - wykonującej ten właśnie długo wyczekiwany ruch/krok w kierunku zwierząt.

\section{Wchodzenie w konteksty (monografia kontekstowa)}

Jak wspomniałam, przy każdym nowym temacie Jarzyna najpierw szeroko zajmuje się opisem wydarzeń, sytuacji, interdyscyplinarnych badań, niezależnie od tego, czy chodzi tu o rzeź psów stambulskich, sytuację (prawną) zwierząt w tzw. Trzeciej Rzeszy ${ }^{1}$, stosunek Kościoła katolickiego do zwierząt, czy o zagadnienie „zwierzyny łownej” i języka łowieckiego. Każdy z tych tematów (wymienionych przeze mnie wyłącznie przykładowo) jest starannie prezentowany, autorka „mapuje” kolejne pola zainteresowań, odsyłając czytelników do rozległych sieci kontekstów, połączeń, synaps. To dowód na niezwykle gruntowne oczytanie badaczki. $\mathrm{W}$ tak przekrojowych opisach tkwi jednak niebezpieczeństwo dla pracujących komparatystycznie i interdyscyplinarnie literaturoznawców (i literaturoznawczyń) - nie sposób bowiem przy takiej liczbie wprowadzanych

${ }^{1}$ Określenie „tzw. Trzecia Rzesza” stosuje się coraz częściej w niemieckich pracach naukowych, wskazując na to, że używana przez narodowych socjalistów nazwa była terminem propagandowym, pomijającym Republikę Weimarską (Cesarstwo Rzymskie Narodu Niemieckiego to Pierwsza Rzesza, a Cesarstwo Niemieckie zjednoczone przez Ottona von Bismarcka to Druga Rzesza). 
do pracy kontekstów (mimo że były one rozpracowywane niegdyś na potrzeby pojedynczych artykułów) zachować koniecznej precyzji i ich w pełni naukowo "ogarnąć".

I tak, w przypadku tematu zagłady Ormian (oraz zestawianej z nią rzezi psów stambulskich) ${ }^{2}$ pojawia się sformułowanie, że „oba [wydarzenia - R.M.] $\mathrm{z}$ różnych przyczyn wciąż nie posiadają ugruntowanego miejsca $\mathrm{w}$ historii” (s. 109). Trudno się z tą tezą zgodzić. Po pierwsze, w takim (porównawczym, antycypacyjnym) zestawieniu obu faktów nadajemy tragedii porzuconych na wyspie Sivriada stambulskich psów znaczenie szczególne, mimo że na bezsensowne cierpienia zwierząt zadawane im przez ludzi, a kończące się często wręcz wymarciem konkretnego gatunku, można wskazać również w wielu innych kontekstach (badaczka odwołuje się gwoli uczciwości naukowej też do dalszych krajów i sytuacji, kiedy w podobny sposób pozbywano się zwierząt, ale czyni to jakby „na marginesie”). Można opisywać rzeź kotów w osiemnastowiecznej Francji albo cierpienia zadawane dziś w Hiszpanii psom galgos. Mimo coraz bardziej wpływowej od lat 50. XX wieku historii codzienności i mentalności nie posiadamy do dziś systematyzujących prac naukowych poświęconych historii zwierząt w ogóle - są to często studia „okolicznościowe” (dotyczące na przykład zwierząt $\mathrm{w}$ okopach pierwszej wojny światowej) czy regionalne, pokazujące raczej epizody (jednej?) wielkiej historii. $\mathrm{W}$ takim ujęciu zawsze możemy odnieść wrażenie, że któryś $\mathrm{z}$ wątków wykorzystywania zwierząt i zadawania im cierpienia jest nie dość opisany.

Po drugie, trudno się zgodzić $\mathrm{z}$ twierdzeniem, że zagłada Ormian nie ma „ugruntowanego miejsca w historii”. Przykłady, które podaje Anita Jarzyna na poparcie swojej tezy, niestety się nie bronią. I tak choćby Historia Turków Jean-Paula Roux (1925-2009), na którą badaczka się powołuje, ukazała się w oryginale w $1984 \mathrm{roku}$, na długo przed tym, nim kolejne państwa europejskie uznały zagładę Ormian za ludobójstwo w sensie prawnym. (Procesy przeciwko odpowiedzialnym za mordy rozpoczęły się wprawdzie już w latach 20 . XX wieku, ale na arenie międzynarodowej zbrodnię tę uznano dość późno - Polska na przykład uczyniła to dopiero w 2005 roku). Genocyd Ormian uważa się dziś za drugi po Szoa najlepiej udokumentowany i znany w ogóle. Wydarzenia te zyskały też niebywale szybko reprezentację literacką - już w 1933 roku ukazały się dwa tomy powieści Franza Werfla Die vierzig Tage des Musa Dagh, które w błyskawicznym wręcz tempie zostały przetłumaczone na język polski: pierwszy tom Muza Dag pod tytułem Potop ukazał się w 1935 roku w tłumaczeniu Olgierda Mierowskiego, autorem przekładu drugiego tomu - Czterdzieści dni (1936) - był Wiktor Halski. O powieści urodzonego w Pradze austriackiego pisarza Franza

2 W tekście Jarzyny pojawiają się raczej określenia: „masakra psów”, „rzeź Ormian”. W zasadzie mogłyby one być wymienne. $Z$ uwagi na uznanie przez coraz więcej państw mordów na społeczności ormiańskiej za ludobójstwo posługuję się w niniejszej recenzji w odniesieniu do wydarzeń z 1915 r. terminem „zagłada”. 
Werfla autorka wprawdzie wspomina, ale najwidoczniej nie przywiązuje do niej większej wagi, nie zajmuje się ani jej pacyfistycznym kontekstem, ani recepcją. Tezy Anity Jarzyny o „zapomnianym ludobójstwie” nie da się obronić, choć jest ona właściwie zapożyczona z tytułu polskiego tłumaczenia książki francuskiego historyka Yves'a Ternona Ormianie. Historia zapomnianego ludobójstwa. W oryginalnym tytule pochodzącej z 1977 roku, a przetłumaczonej na język polski dopiero w 2005 roku, pracy nie znajdziemy jednak żadnego przymiotnika: Les Arméniens, histoire d'un génocide. Jeśli polski czytelnik, a konkretnie Wydawnictwo Uniwersytetu Jagiellońskiego, uznał/o to ludobójstwo za „zapomniane”, to był to niestety chwyt rodem z tabloidów. Tego typu usterki i niekonsekwencje - które mogą się zdarzyć przez chwilową nieuwagę każdemu naukowcowi - powinna była jednak wyłapać jeśli nie redakcja Wydawnictwa Uniwersytetu Łódzkiego, gdzie ukazała się monografia Anity Jarzyny, to na pewno cała grupa recenzentów (peer review), w których ręce trafiały kolejne artykuły, późniejsze podrozdziały Post-koiné...

Jeśli autorka pisze o zoo powstałym na terenie obozu koncentracyjnego w Buchenwaldzie i wspomina przy tej okazji, że miało ono tė̇ „służyć [...] rozrywce [...] mieszkańców pobliskiego Weimaru" (s. 164), to pomija fakt, że tak naprawdę istniały dwie jego części: jedna ze ssakami (małpami, niedźwiedziami), założona $\mathrm{z}$ myślą o wysokich rangą pracownikach obozu i ich rodzinach, oraz druga, ptaszarnia, położona nieco na uboczu, do której wstęp mieli w wolnych dniach rzeczywiście weimarczycy.

To oczywiście szczegóły, ale - oprócz tego, że diabeł tkwi w szczegółach przeszkadzają one nieco w gładkiej lekturze Post-koiné...

\section{Wchodzenie w pamięć}

Anita Jarzyna stara się w swojej publikacji w ramach postulowania i opisywania języka wrażliwego na sprawy zwierząt konsekwentnie poruszać wątek pamięci, a konkretnie - braku wydarzeń związanych z historią zwierząt w swego rodzaju postantropocentrycznej historii powszechnej. Stwierdzenie tego braku pojawia się już w momencie opisu rzezi psów stambulskich (i przewija się w zasadzie przez całą monografię) - w tym miejscu badaczka konstatuje, że masakra ta zajmuje „marginalne miejsce [...] w historiografii i tekstach kultury”, i że „w opowiadaniu o masowym zabijaniu zwierząt jesteśmy jeszcze mniej zaawansowani niż w opowiadaniu o ludobójstwach" (s. 131). Obie tezy zapraszają wręcz do polemiki: pierwsza - bo choć historia codzienności i historia mentalności rozwijają się prężnie już od dawna, to jednak los zwierząt nigdy nie znajdował się w ich centrum. Masakra psów stambulskich nie jest tu więc 
wyjątkiem, ale raczej smutną regułą. Drugie stwierdzenie może wywoływać czytelniczy niepokój, zawiera bowiem utopijną myśl, że zbrodnie wobec zwierząt mogłyby być w podobny sposób opowiadane i ścigane co zbrodnie wobec ludzkości. Niepokój może się tu wiązać z ich możliwą konkurencyjnością: zamiast nie dopuszczać do ludobójstw i je ścigać (na przykład masowe utonięcia uchodźców w Morzu Śródziemnym), mielibyśmy się zajmować „opowiadaniem o masowym zabijaniu zwierząt". Badaczka nie zapomina jednak o koncepcji pamięci wielokierunkowej Michaela Rothberga, starającej się przeciwdziałać właśnie konkurencyjności różnych pamięci. Kładzie ona nacisk na analogie i współdziałanie. W procesie uwalniania się od paradygmatu antropocentryzmu nauki historyczne przeszły $\mathrm{w}$ ostatnich dziesięcioleciach daleko idące zmiany: od francuskiej szkoły Annales i tworzenia wspomnianej tu już historii mentalności, od podziału - śladami Fernanda Braudela - historii na losy zdarzeń, historię długiego trwania oraz geohistorię, poprzez pisaną w ostatnich dziesięcioleciach coraz częściej histoire croisée, po historię kulturową. Zanim możliwa będzie „wspólna” historia powszechna, niewykluczająca zwierząt, warto zająć się tworzeniem historii (kulturowej) zwierząt, będącej formą pamięci o nich. Zalążkiem takiego podejścia są już teraz monografie poświęcone poszczególnym gatunkom, jak na przykład Szczur Jonathana Burta ${ }^{3}$ albo Wisent-Wildnis und Welterbe... Thomasa M. Bohna, Aliaksandra Dalhouskiego i Markusa Krzoski ${ }^{4}$, zajmująca się żubrem w polsko-białoruskim Białowieskim Parku Narodowym, oraz oczywiście studia przekrojowe jak Zwierzęcy punkt widzenia Érica Barataya.

\section{Wchodzenie w emocje}

Autorka skupia się w Post-koiné... również na „kwestii zwierzęcej emocjonalności i jej miejsca w języku” (s. 489). Można oczywiście powątpiewać, czy możliwy jest inny niż etologiczny opis owej emocjonalności, badaczka jednak wychodzi od tezy, że język literacki - podobnie jak fikcja literacka - rzeczywiście ma taką szansę. Powołuje się przy tym na twierdzenia innych naukowców - między innymi Anny Barcz i Pawła Majewskiego ${ }^{6}$, choć Majewski sceptycznie od-

${ }^{3}$ J. Burt: Szczur. Przeł. A. Leśniak. Kraków 2006.

${ }^{4}$ Th.M. Bohn, A. Dalhouski, M. Krzoska: Wisent-Wildnis und Welterbe. Geschichte des polnisch-weißrussischen Nationalparks von Białowieża. Köln-Weimar-Wien 2017.

${ }^{5}$ A. Barcz: Realizm ekologiczny. Od ekokrytyki do zookrytyki w literaturze polskiej. Katowice 2016.

${ }^{6}$ P. Majewski: Lew, który mówi. Esej o granicach językowego wyrazu doświadczenia. Warszawa 2018. 
nosi się do możliwości przedstawiania zwierzęcego punktu widzenia w sytuacji, kiedy nie mamy (przecież!) ze zwierzętami wspólnego języka. W ostatniej części tomu przeważają opisy codzienności dzielonej ze zwierzęcymi przyjaciółmi, opisy bliskości - to interakcje dwóch równorzędnych podmiotów. Niektóre tezy Jarzyny wydają mi się sformułowane nieco na wyrost, czym innym są bowiem literackie próby wyrażenia zwierzęcej emocjonalności (stanowią one raczej sprawdzian ludzkiej wrażliwości), czym innym rzeczywista emocjonalność zwierząt. Relacje ofiar oraz świadków Szoa badaczka czyta jako relacje o ludziach i nie-ludziach, i dochodzi do wniosku, że „[w] konsekwencji [...] te relacje dają wgląd w najbardziej podstawowe emocje prześladowanej istoty, niezależnie od jej przynależności gatunkowej pozwalają wyobrazić sobie, jak przeżywa ona polowanie" (s. 185 n.). Stwierdzenie to zawiera - moim zdaniem - najważniejszy paradoks posthumanistycznych opisów z tomu Jarzyny. To projekcja uczuć ludzkich na zwierzęta. Oczywiście możemy sobie wyobrazić, że zwierzęta w sposób podobny do ludzi przeżywają lęk, na dodatek lęk przed śmiercią (dysponujemy odpowiednimi badaniami etologicznymi, obserwujemy takie zachowania zwierząt w przestrzeni - niemalże - publicznej), ale nic ponad to. Autorka balansuje tu między przedstawieniami dokumentalnymi a językiem literackim, którego polem działalności jest jednak sfera imaginacji.

\section{Wchodzenie w język}

Najważniejszym tematem pracy Anity Jarzyny jest język - czy to język poetycki, czy ogólnie: literacki, czy język refleksji posthumanistycznej, czy w końcu nasz język codzienny. To on jest wspólnym mianownikiem wszystkich - przypomnijmy, napisanych niezależnie od siebie - rozdziałów Post-koiné... To język poezji, który jest najbardziej współczujący, „emancypujący i krytyczny, odkłamujący na przykład fałszywe obrazy lotów w kosmos z udziałem zwierząt", pisze krytyczka na marginesie wiersza Zbigniewa Herberta Naprzód pies (s. 361). Czasami autorka tworzy „biografie słów”, zajmując się chociażby językiem łowieckim i jego specyficzną leksyką, która z jednej strony - jak każdy socjolekt profesjonalizuje opis wykonywanych czynności, z drugiej jednak - metaforyzuje i przede wszystkim tabuizuje daną profesję. Zdaniem Jarzyny kontynuacja antropocentrycznego punktu widzenia jest $\mathrm{w}$ dzisiejszych czasach „gwałtem na języku" (s. 313). Zwierzę jest bowiem zarówno bohaterem opowieści, istotą sprawczą, jak i „jednostką języka” (s. 33).

W zasadzie w całej monografii autorka zadaje pytanie o miejsce, jakie zwierzęta zajmują w języku; nie chodzi jej jednak o „infantylizujące antropomorfizacje" (s. 444), lecz o rzeczywiste próby opisania wspólnego świata: ludzkiego 
i nie-ludzkiego. Literackie zapisy „międzygatunkowego porozumienia” (s. 493) są bowiem przede wszystkim pracą w języku.

Post-koiné... Anity Jarzyny to erudycyjna i inspirująca praca, pogłębiająca polskie studia nad językiem postantropocentrycznym. Odwołuje się ona do licznych kontekstów, rozszerza pola badań, buduje analogie. Czasem do wywodów Anity Jarzyny-badaczki przedostaje się moralizatorski ton Anity Jarzyny-aktywistki, argumentującej przeciwko myślistwu, jedzeniu mięsa i masowym hodowlom zwierząt czy fermom zwierząt futerkowych. Nie sposób jednak odzielić od siebie tych dwóch ról przy takiej tematyce i - jak sądzę - nie trzeba się wcale przed osobistym tonem bronić. Zastanawiają jednak chwyty retoryczne - jak ten, że „Herbert i Włodek zrozumieli to, czego do dziś nie rozumieją historycy...” (s. 382) - służące budowaniu sztucznego napięcia między światem poezji („czułą sondą" kultury) a obszarem (nieczułych?) badań historiograficznych. Jeśli erudycyjnej pracy Jarzyny można coś zarzucić, to jest to właśnie niewystarczająca precyzja $\mathrm{w}$ przedstawianiu przywoływanych $\mathrm{w}$ analizach kontekstów interdyscyplinarnych. Badania historiograficzne już od dłuższego czasu otwierają się na zwierzęta nieludzkie, idą nawet krok dalej, skupiając się na środowisku naturalnym ${ }^{7}$ (a - przypomnijmy - tylko jeden z autorów przywołanych przez badaczkę zajmuje się „przyrodopisaniem”). Szkoda, że Anita Jarzyna nie chce dostrzec tego procesu.

Renata Makarska - prof. dr, kieruje Zakładem Polonistyki na Wydziale Translatologii, Lingwistyki i Kulturoznawstwa Uniwersytetu im. Jana Gutenberga w Moguncji/ Germersheim. Zajmuje się literaturą postemigracyjną, nowymi mniejszościami w Europie Środkowo-Wschodniej, transkulturowością oraz przekładem. Najnowsze publikacje w języku polskim: Poetyka migracji. Doświadczenie granic w literaturze polskiej przełomu XX i XXI wieku (red. z Przemysławem Czaplińskim i Martą Tomczok; 2013), Historie i narracje. Od historii lokalnej do opowieści postantropocentrycznej (red.; 2019), Wyjść tlumaczowi naprzeciw. Miejsce tłumacza $w$ najnowszych badaniach translatologicznych (red. z Jadwigą Kitą-Huber; 2020).

${ }^{7}$ Por. m.in. „Teksty Drugie” 2017, nr 2: Środowiskowa historia Zagłady; M. Praczyk: Pamięć środowiskowa we wspomnieniach osadników na „Ziemiach Zachodnich”. Poznań 2018. 